\title{
PENGEMBANGAN MODEL PENILAIAN AUTENTIK PADA KURIKULUM 2013 DI SEKOLAH DASAR
}

\author{
Yuyun Dwi Haryanti ${ }^{1}$, Sapriya ${ }^{2}$, Tegar Pambudhi ${ }^{3}$ \\ ${ }^{1}$ Universitas Majalengka, ${ }^{1,2,3}$ Universitas Pendidikan Indonesia \\ 1yuyundwiharyanti18@gmail.com
}

\begin{abstract}
Authentic assessment is an assessment that requires students to be able to use knowledge, display attitudes, and skills acquired through real tasks in the real situation in the learning process. This study aims to produce an authentic curriculum assessment model book 2013 that meets eligibility so that teachers can use it in conducting authentic assessment on aspects of knowledge, attitudes, and skills. The research design used is the type of research development. The research procedure refers to the Borg and Gall steps, namely: 1) potential and problems, 2) information gathering, 3) product design, 4) design validation, and 5) product revision. Data collection techniques through interviews and questionnaires. The results of the needs analysis through interviews with elementary school teachers that teachers still find it difficult to develop authentic assessment. The results of the needs analysis questionnaire obtained a score of $75 \%$ means the teacher needs an authentic curriculum assessment book 2013. The results of the Feasibility Test on the subject matter experts, content, and language used in the authentic curriculum assessment model book 2013 in Elementary Schools obtained a score of 94\% with the category "Very Valid ". Based on the results of the study, it can be concluded that the book model for developing authentic curriculum assessment in elementary schools meets the eligibility for teacher use as an authentic assessment guide that is equipped with a theoretical foundation, knowledge assessment, attitude assessment, and skills assessment.
\end{abstract}

Keywords: authentic assessment; curriculum 2013; model development

\begin{abstract}
Abstrak
Penilaian autentik merupakan penilaian yang menghendaki peserta didik agar mampu menggunakan pengetahuan, menampilkan sikap, dan keterampilan diperoleh melalui tugas nyata pada situasi sesungguhnya dalam proses pembelajaran. Penelitian ini bertujuan untuk menghasilkan buku model penilaian autentik kurikulum 2013 yang memenuhi kelayakan sehingga dapat digunakan guru dalam melakukan penilaian autentik pada aspek pengetahuan, sikap, dan keterampilan. Desain penelitian yang digunakan jenis penelitian pengembangan atau Research and Development. Prosedur penelitian mengacu pada langkah-langkah Borg and Gall yaitu: 1) potensi dan masalah, 2) pengumpulan informasi, 3) desain produk, 4) validasi desain, dan 5) revisi produk. Teknik pengumpulan data melalui wawancara dan angket. Hasil analisis kebutuhan melalui wawancara pada guru Sekolah Dasar bahwa guru masih merasa kesulitan dalam mengembangkan penilaian autentik. Hasil angket analisis kebutuhan diperoleh skor sebesar $75 \%$ berarti guru membutuhkan buku penilaian autentik kurikulum 2013. Hasil Uji kelayakan pada ahli materi, isi, dan bahasa yang digunakan pada buku model penilaian autentik kurikulum 2013 di Sekolah Dasar diperoleh skor sebesar 94\% dengan kategori "Sangat Valid". Berdasarkan hasil penelitian, dapat disimpulkan bahwa buku panduan model penilaian autentik kurikulum 2013 di Sekolah Dasar memenuhi kelayakan untuk digunakan guru sebagai petunjuk penilaian autentik yang dilengkapi landasan teori, penilaian pengetahuan, penilaian sikap, dan penilaian keterampilan.
\end{abstract}

Kata Kunci: kurikulum 2013; pengembangan model; penilaian autentik

\begin{tabular}{llll}
\hline Received & $: 2020-07-06$ & Approved & $: 2020-11-30$ \\
Reviesed & $: 2020-11-29$ & Published & $: 2021-01-31$ \\
\hline
\end{tabular}

Jurnal Cakrawala Pendas is licensed under a Creative Commons AttributionShareAlike 4.0 International License. 


\section{Pendahuluan}

Kurikulum yang berlaku saat ini di Indonesia adalah Kurikulum 2013 atau dengan sebutan Kurtilas. Kurikulum ini pada pendidikan dasar menitikberatkan pada penilaian hasil belajar peserta didik meliputi penilaian sikap, pengetahuan, dan keterampilan (Kemendikbud, 2016). Penilaian hasil belajar peserta didik pada kurikulum 2013 disebut dengan penilain autentik. Penilaian autentik adalah bentuk penilaian yang menghendaki peserta didik agar mampu menggunakan pengetahuan, menampilkan sikap, dan keterampilan yang diperoleh melalui proses pembelajaran dalam melakukan tugas nyata siswa pada situasi sesungguhnya (Mendikbud, 2014).

Penilaian autentik peserta didik penting dilakukan guru agar dapat memberikan gambaran perkembangan peserta didik. Gambaran perkembangan tersebut dapat dijadikan guru dalam mengindentifikasi permasalahan yang dihadapi peserta didik. Hasil identifikasi guru tersebut dijadikan pedoman guru untuk melakukan tindakan yang tepat dalam pemecahan permasalahan peserta didik. Penilaian autentik tidak hanya dilakukan di akhir semester melainkan dilakukan secara integratif melalui proses pembelajaran (Yunus Abidin, 2016). Sejalan dengan pendapat (Endra et al., 2015) bahwa penilaian autentik untuk menilai peserta didik secara komprehensif pada ranah sikap, keterampilan dan pengetahuan yang dilakukan guru dari awal pembelajaran, proses pembelajaran hingga akhir pembelajaran.

Penilaian autentik dapat memberikan berbagai informasi peserta didik melalui pengamatan nyata yang dilakukan dalam pembelajaran (Yamin, 2018). Penilaian autentik pada kurikulum 2013 dilakukan melalui pendekatan saintifik dalam proses pembelajaran. Guru berperan sebagai fasilitator dalam mendesain pembelajaran untuk mencapai tujuan pembelajaran (Haryanti \& Saputra, 2019). Guru menggunakan pendekatan saintifik sehingga dapat menjebatani peserta didik dalam memahami materi yang diajarkan di kelas dikaitkan dengan kondisi nyata yang dialami peserta didik dalam kehidupan sehari-hari (Baiduri, 2019). Penilaian autentik menggunakan berbagai teknik penilaian untuk mengungkapkan, membuktikan atau menunjukkan secara tepat dalam mencapai tujuan pembelajaran dan kompetensi yang benar-benar dikuasai dan dicapai peserta didik (Wildan, 2017).

Implementasi penilaian autentik saat ini belum sesuai dengan peraturan penilaian yang berlaku pada kurikulum 2013. Berdasarkan hasil penelitian (Ani, 2014) bahwa penilaian hasil belajar yang dilakukan guru diukur pada pengetahuan melalui tes tertulis sedangkan sikap dan keterampilan tidak dinilai. Sejalan dengan hasil penelitian (Daji et al., 2019) masih ditemukan guru dalam melakukan penilaian di lapangan masih menggunakan pola lama yaitu hanya menilai aspek kognitif peserta didik. Berkaitan dengan pendapat tersebut bahwa pencapaian penilaian hasil belajar peserta didik yang paling utama dilakukan guru adalah kompetensi pengetahuan. Sejalan pendapat (Enggarwati, 2015) bahwa kelemahan penilaian autentik pada kurikulum 2013 yaitu guru merasa rumit, butuh waktu, dan tenaga yang banyak untuk membuat instrumen penilaian karena terlalu banyak aspek yang dinilai. Meskipun guru sudah mendapatkan pelatihan implementasi kurikulum 2013 namun merasa materi yang disampaikan bersifat abstrak sehingga sulit diterapkan khususnya di Sekolah Dasar. Munawati (2017) mengungkapkan bahwa kelemahan pada implementasi penilaian autentik ada pada guru. Dimana guru memiliki keterbatasan dalam pengetahuan terkait konsep pembelajaran dan penilaian autentik sehingga dianggap terlalu sulit diimplementasikan.

Kelemahan implementasi penilaian autentik juga ditemukan pada Sekolah Dasar di Majalengka. Berdasarkan hasil observasi sebanyak 6 guru di SD Negeri Jatipamor 1, SD Negeri Majalengka Kulon II, dan SD Negeri Munjul 1 menunjukkan bahwa penilaian autentik belum dilakukan sepenuhnya oleh guru sesuai dengan standar penilaian pada kurikulum 2013. 
Penilaian yang dilakukan guru selama ini masih menitikberatkan pada aspek pengetahuan. Namun, penilaian pada aspek sikap dan ketrampilan dikesampingkan. Guru meskipun menggunakan penilaian sikap dan keterampilan namun masih bersifat subjektif. Hasil wawancara pada enam guru mengatakan bahwa penilaian yang digunakan secara teksbook. Guru hanya berpedoman pada buku guru saja tanpa mengembangkan sendiri disesuaikan dengan kompetensi dasar yang ingin dicapai. Padahal penilaian autentik pada kurikulum 2013 dikembangkan oleh guru itu sendiri. Selain itu, guru belum paham sepenuhnya mengenai penilaian autentik terutama dalam merencanakan penilaian, pelaksanaan penilian serta pada pelaporan penilaian. Guru berharap adanya buku panduan model penilaian autentik pada kurikulum 2013 yang mudah dipahami sehingga mudah diimplementasikan pada sekolah dasar.

Permasalahan diatas, diperlukan solusi pemecahan sehingga guru Sekolah Dasar di Majalengka dapat mengimplementasikan penilaian autentik sesuai dengan tuntutan Kurikulum 2013. Berdasarkan hasil wawancara dan angket analisis kebutuhan dapat disimpulkan bahwa guru memerlukan buku panduan model penilaian autentik yang mudah dipahami dan digunakan. Buku model penilaian autentik difokuskan pada model pembelajaran berbasis masalah yaitu pada kelas IV Tema 8 "Daerah Tempat Tinggalku". Adapun produk yang dikembangkan pada buku model penilaian autentik ini meliputi instrumen penilaian pengetahuan, sikap dan keterampilan, teknik penilaian, langkah-langkah penilaian, dan cara pengolahan penilaian.

\section{Metode Penelitian}

Desain penelitian yang digunakan dalam penelitian ini termasuk jenis Research and Development atau merupakan penelitian pengembangan. Prosedur penelitian mengacu pada model Gall, Gall, \& Borg (2003) menjelaskan serangkaian atau langkah yang harus ditempuh dalam pendekatan ini, yaitu : (1) potensi dan masalah; (2) pengumpulan informasi; (3) desain produk; (4) validasi desain; (5) perbaikan desain; (6) uji coba produk; (7) revisi produk; (8) uji coba pemakaian; (9) revisi produk; dan (10) pembuatan produk masal. Pada penelitian ini hanya pada langkah keempat yaitu validasi produk.

Penelitian ini bertujuan untuk menghasilkan produk pengembangan model penilaian autentik pada kurikulum 2013 di SD khususnya di Majalengka. Penelitian ini menguji kevalidan atau kelayakan produk melalui validator ahli dalam penilaian kurikulum 2013 melibatkan Instruktur kurikulum 2013, dosen ahli evaluasi, dan praktisi dari guru SD. Adapun subjek penelitian adalah SD Negeri di Majalengka yaitu SD Majalengka Kulon II, SD Munjul I, dan SD Jatipamor I. Setiap sekolah yang digunakan peneliti mempunyai karakteristik yang berbeda dari tingkat penerapan kurikulum 2013 sehingga akan menghasilkan hasil penelitian yang valid.

Rancangan perlakuan pada kegiatan penelitian ini secara skematis adalah sebagai berikut:

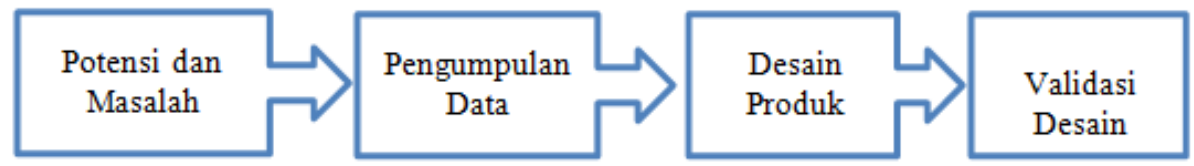

Gambar. 1 Prosedur Penelitian Pengembangan Gall, Gall, \& Borg (2003)

Potensi dan Masalah dalam penelitian ini ditunjukkan melalui data empirik. Data diperoleh berupa hasil analisis kurikulum, jurnal, buku guru dan buku siswa kurikulum 2013, buku referensi, observasi dan dokumentasi. Pengumpulan Data dilakukan peneliti mengumpulkan berbagai masalah dan potensi secara factual dan up to date. Desain Produk yang 
dihasilkan peneliti berupa buku model penilaian autentik pada kuikulum 2013 di SD. Selain buku model peneliti mendesain lembar validasi dan draf model. Validasi Desain dilakukan peneliti dengan menguji produk kepada validator dimana validator dari instruktur kurikulum, dosen, dan praktisi lapangan.

Instrumen penelitian yang digunakan selama penelitian ini berupa analisis kebutuhan dengan menggunakan angket, produk buku model, lembar validasi, dan angket. Buku model penilaian autentik meliputi contoh instrumen penilaian pengetahuan, sikap, dan keterampilan. Lembar Validasi dilakukan oleh 3 validator yaitu instruktur kurikulum 2013, dosen, dan praktisi lapangan. Angket digunakan dalam analisis kebutuhan terkait desain buku model penilaian autentik. Teknik analisis data berupa deskripsi kualitatif dalam penilaian buku model penilaian autentik. Hasil analisis data yang dilakukan validator kemudian disimpulkan apabila mencapai 80\% maka produk yang dihasilkan memenuhi kriteria kelayakan atau kevalidan.

\section{Hasil dan Pembahasan}

Analisis kebutuhan dilakukan di SD Negeri yang berada di kecamatan Majalengka. Analisis kebutuhan dilakukan dengan wawancara dengan guru kelas IV serta pengisian angket. Hasil analisis kebutuhan pada wawancara dan angket dapat diuraikan sebagai berikut:

Pertama, Hasil wawancara di lakukan di SD yang ada di kecamatan Majalengka dengan narasumber guru kelas IV sebanyak 6 orang. Pertanyaan wawancara terdiri dari 26 pertanyaan. Adapun aspek pertanyaan wawancara adalah sebagai berikut: 1) persepsi guru tentang penilaian autentik, 2) rubrik penilaian autentik, 3) tugas penilaian autentik, 4) pengalaman mengembangkan penilaian autentik, 5) langkah-langkah penilaian autentik, 6) kesulitan guru terhadap penilaian autentik, dan 7) harapan guru terhadap penilaian autentik. Berdasarkan hasil wawancara dengan 6 narasumber dari guru kelas IV di Sekolah Dasar mengenai pemahaman penilaian autentik pada kurikulum 2013 mengetahui namun tidak mendalam. Guru mayoritas melakukan penilaian sesuai dengan buku pedoman guru yang ada pada buku guru kurikulum 2013. Guru masih kesulitan dalam implementasi penilaian autentik pada proses pembelajaran berlangsung. Penilaian lebih menekankan pada penilaian pengetahuan daripada penilaian sikap dan keterampilan. Penilaian sikap paling sulit dilakukan oleh guru. Hasil penelitian Munawati (2017) yang dilakukan di SD Negeri Pujokusuman 1 Yogyakarta bahwa guru mengalami kesulitan dalam menilai sikap siswa dalam proses pembelajaran di kelas sehingga guru focus pada penilaian pengetahuan. Selain itu, kelemahan penilaian yang dilakukan guru masih cenderung pada suatu mata pelajaran tertentu seperti pada Bahasa Indonesia dan Matematika. Baiduri (2019) mengungkapkan bahwa penilaian autentik cenderung pada masalah konstekstual mata pelajaran Matematika. Padahal dalam penilaian autentik menggunakan pendekatan tematik integratif yaitu mengintegrasikan beberapa mata pelajaran ke berbagai tema (Endra et al., 2015).

Kedua, Angket pada analisis kebutuhan penilaian autentik di SD pada kurikulum 2013 meliputi 7 aspek adalah sebagai berikut: 1) Persepsi guru tentang penilaian autentik; 2) Rubrik penilaian autentik; 3) Tugas penilaian autentik; 4) Pengalaman mengembangkan penilaian autentik; 5) Langkah-langkah penilaian autentik; 6) Kesulitan guru terhadap penilaian autentik; dan 7) Harapan guru terhadap penilaian autentik. Instrumen pada angket terdiri dari kisi-kisi, rubrik penilaian, lembar angket, dan pedoman penilaian. Responden sebanyak 6 orang dengan memberikan ceklis $(\sqrt{ })$ pada kriteria jawaban yang telah tersedia dengan menggukan skala likert $1-4$.

Angket sebelum diujicobakan terlebih dahulu dikonsultasikan kepada ahli yaitu pada dosen yang ahli bidang evaluasi. Masukan terkait instrumen angket yang dikembangkan 
berdasarkan masukan dari dosen ahli evaluasi adalah sebagai berikut: 1) angket yang dibuat diberikan petunjuk yang jelas, sehingga narasumber tidak kebingungan dalam pengisian angket; 2) angket menggunakan skala likert 1-4 agar narasumber menghindari tidak memilih nilai tengah seperti skala 1-5 kemungkinan memilih skor 3; dan 3) pertanyaan yang dibuat jangan mudah dipahami sehingga tidak menimbulkan penafsiran ganda. Adapun hasil rekapitulasi angket dapat dilihat pada tabel 1 sebagai berikut:

Tabel 1 Hasil Rekapitulasi Angket

\begin{tabular}{cccccccccc}
\hline Responden & \multicolumn{1}{c}{ Aspek } & Skor & Presentase \\
& $\mathbf{1}$ & $\mathbf{2}$ & $\mathbf{3}$ & $\mathbf{4}$ & $\mathbf{5}$ & $\mathbf{6}$ & $\mathbf{7}$ & & \\
\hline 1 & 3 & 3 & 2 & 3 & 3 & 2 & 3 & 19 & 68 \\
2 & 3 & 3 & 3 & 3 & 3 & 3 & 3 & 21 & 75 \\
3 & 3 & 3 & 3 & 3 & 3 & 3 & 3 & 21 & 75 \\
4 & 3 & 3 & 4 & 3 & 3 & 3 & 3 & 22 & 79 \\
5 & 3 & 3 & 3 & 4 & 3 & 3 & 3 & 22 & 79 \\
& \multicolumn{1}{c}{ Nilai Akhir } & & & & 105 & $75 \%$ \\
\hline
\end{tabular}

Berdasarkan hasil angket pada Tabel 1 dengan 6 narasumber dari guru kelas IV di Sekolah Dasar mengenai analisis kebutuhan penilaian autentik pada kurikulum 2013 diperoleh skor 105 dengan tingkat presentase $75 \%$ hal ini dapat disimpulkan bahwa guru "membutuhkan" buku model penilaian autentik kurikulum 2013 khususnya pada sub tema 8 "Daerah Tempat Tinggalku" yang mencakup ranah kognitif, afektif, dan psikomotor.

Ketiga, Draf produk yang dihasilkan dalam penelitian ini adalah buku model penilaian autentik berupa buku petunjuk bagi guru SD pada kurikulum 2013 subtema 8 "Daerah Tempat Tinggalku". Buku ini bertujuan sebagai pedoman guru dalam melakukan penilaian autentik. Adapun langkah-langkah yang dilakukan dalam mengembangkan produk adalah sebagai berikut: 1) membuat desain buku model berupa buku petunjuk penilaian autentik disesuaikan dengan spesifikasi produk yang dikembangkan; 2) menyusun instrumen penilaian autentik; dan 3) sistem penilaian (Bhakti, 2014). Adapun desain buku model berupa buku petunjuk penilaian autentik dapat dilihat pada Tabel 2 berikut ini:

Tabel 2 Desain Buku Model Penilaian Autentik

No
Desain cover dibuat dengan bertuliskan "Penilaian Autentik
di SD". Warna pada cover perpaduan antara warna biru
muda, ungu, putih, hijau, cokelat, orange. Gambar cover
bertemakan sekolah dasar.




Bagian Bab II membahas "Penilaian Autentik" meliputi:
hakikat penilaian autentik, tujuan penilaian autentik,
karakteristik penilaian autentik, prinsip-prinsip penilaian
autentik, dan pentingnya penilaian autentik.

Buku model penilaian autentik di SD sebagai petunjuk penilaian kurikulum 2013 yang dikembangkan pada analisis kebutuhan guru sekolah dasar di Majalengka. Buku model didesain untuk dijadikan pedoman guru dalam melaksanakan penilaian autentik pada kurikulum 2013 khususnya siswa kelas IV tema" Daerah Tempat Tinggalku". Buku model penilaian ini terdiri dari 5 bab berisikan mengenai konsep penilaian, penilaian autentik, penilaian pengetahuan, penilaian sikap dan penilaian keterampilan pada kurikulum 2013. Esensial dari buku model ini adanya langkah-langkah bagaimana guru dapat mengembangkan penilaian aspek pengetahuan, sikap, dan keterampilan pada kurikulum 2013. Guru dapat mengembangkan penilaian diperlukan langkah-langkah jitu sehingga penilaian bersifat autentik terhadap siswa yang dinilai dari aspek pengetahuan, sikap, dan keterampilan. Penilaian dilakukan meliputi 3 fase yaitu sebelum pembelajaran, selama proses pembelajatan dan setelah proses pembelajaran (Villarroel et al., 2019).

Keempat, Uji kelayakan dilakukan untuk mengetahui validitas buku model penilaian autentik di SD. Uji kelayakan dilakukan tiga responden yaitu dosen, instruktur kurikulum, dan praktisi. Adapun hasil uji kelayakan buku model penilaian autentik di SD berikut.

Tabel 3 Uji Kelayakan

\begin{tabular}{cccccc}
\hline Ahli & & Aspek & Skor & Presentase \\
& 1 & 2 & 3 & & \\
\hline 1 & 34 & 20 & 15 & 69 & $95,8 \%$ \\
2 & 33 & 20 & 14 & 67 & $93 \%$ \\
3 & 32 & 20 & 15 & 67 & $93 \%$ \\
& Skor Rata-rata & 68 & $94 \%$ \\
\hline
\end{tabular}

Berdasarkan tabel diatas, uji kelayakan meliputi aspek materi, isi, dan bahasa yang digunakan pada buku model penilaian autentik di SD. Uji kelayakan diperoleh skor sebesar 68 dengan tingkat presentase sebesar $94 \%$. Hal ini dapat disimpulkan bahwa buku model penilaian autentik di SD dengan kategori "Sangat Valid" artinya buku dapat digunakan sebagai pedoman guru dalam melakukan penilaian autentik.

Kelima, Buku penilaian autentik di SD memenuhi kelayakan untuk digunakan sebagai pedoman penilaian autentik di SD. Adapun catatan dari para ahli mengenai buku model penilaian autentik di SD dapat dilihat pada Tabel 4 berikut. 
Tabel 4 Catatan para Ahli

\begin{tabular}{ccl}
\hline No & Nama & \multicolumn{1}{c}{ Catatan } \\
\hline 1 & Validator 1 & $\begin{array}{l}\text { Struktur buku sangat sistematis sehingga mudah untuk dipahami } \\
\text { isinya. Selain itu, buku tersebut mampu menambah literature } \\
\text { mengenai penilaian autentik, terutama bagi guru sekolah dasar. }\end{array}$ \\
2 & Validator 2 & $\begin{array}{l}\text { Buku penilaian autentik yang disusun sangat layak digunakan karena } \\
\text { memberikan motivasi dan membuat guru kreatif serta menumbuhkan } \\
\text { inspiratif. } \\
\text { Buku yang dikembangkan diharapkan dapat menjadi inspiratif untuk } \\
\text { kemajuan dunia pendidikan. }\end{array}$ \\
\hline
\end{tabular}

Pengembangan model penilaian autentik pada kurikulum 2013 berfokus pada pembelajaran model berbasis masalah. Pengembangan tersebut dikembangkan berdasarkan kelemahan yang ada pada buku guru dan buku siswa kelas IV tema 8 "Daerah Tempat Tinggalku". Adapun kelemahan yang ada pada buku tersebut adalah belum adanya penjabaran secara terperinci mengenai rubrik penilaian pengetahuan, sikap, dan keterampilan. Hasil pengembangan pada buku penilaian autentik dilengkapi dengan teori mengenai penilaian autentik serta implementasi penilaian autentik yang sesuai diterapkan di SD meliputi tiga aspek adalah sebagai berikut:

Pertama, Penilaian pengetahuan pada kurikulum 2013 sebagai penilaian yang membekali siswa agar memiliki pengetahuan faktual, pengetahuan konseptual, pengetahuan prosedural, dan pengetahuan metakognitif (Anderson, L \& Kratwohl, 2015). Pengetahuan faktual disebut pengetahuan dasar yang harus dimiliki dalam mempelajari satu disiplin ilmu atau untuk menyelesaikan masalah dalam disiplin ilmu tersebut. Pengetahuan konseptual adalah pengetahuan yang bersifat lebih kompleks dan tertata. Penilaian konseptual mencerminkan adanya hubungan antara elemen pengetahuan faktual dalam sebuah struktur besar yang memungkinkan elemen-elemen tersebut berfungsi secara bersama-sama. Pengetahuan konseptual memuat ide (gagasan) dalam suatu disiplin ilmu yang memungkinkan orang untuk mengklasifikasikan sesuatu objek serta mengelompokkan (mengkategorikan) berbagai objek.

Pengetahuan prosedural adalah pengetahuan yang lebih tinggi karena berkenaan dengan bagaimana melakukan sesuatu, sebagai contoh mempraktikkan metode-metode penelitian, dan kriteria-kriteria untuk menggunakan keterampilan, teknik, dan metode tertentu. Pengetahuan prosedural berupa rangkaian langkah-langkah yang harus diikuti atau pengetahuan tentang beragam proses. Pengetahuan metakognitif adalah pengetahuan tentang bagaimana berpikir untuk berpikir. Pengetahuan ini berkenaan dengan kemampuan seseorang memilih strategi yang tepat digunakan untuk beragam tugas, kondisi, dan sekaligus berfungsi sebagai control diri. Pengetahuan metakognitif memotivasi siswa untuk menyelesaikan berbagai masalah sesuai dengan konteksnya. Implementasi kurikulum 2013 pada sekolah dasar sesuai dengan Mendikbud (2014) bahwa standar penilaian, siswa SD mencakup penilaian pengetahuan faktual, penilaian pengetahuan konseptual, dan pengetahuan prosedural.

Instrumen penilaian pengetahuan yang digunakan dalam kurikulum 2013 adalah tes tertulis. Tes tertulis adalah tes yang soal dan jawaban yang diberikan kepada siswa dalam bentuk bahan tulisan. Tes tertulis digunakan untuk tes hasil belajar siswa dalam mengukur pengetahuan atau penguasaan objek ukur terhadap seperangkat materi tertentu. Ada beberapa hal yang perlu diperhatikan guru dalam menyusun tes tertulis yang dikutip dari Setiamiharja 
(2012) adalah sebagai berikut:1) Tes tertulis dapat mengukur apa yang dipelajari dalam proses belajar mengajar sesuai dengan tujuan instruksional yang tercantum di dalam kurikulum yang berlaku; 2) Tes yang tersusun benar-benar mewakili bahan yang telah dipelajari; 3) Tes hendaknya disesuaikan dengan aspek-aspek tingkat belajar yang diharapkan; 4) Tes hendaknya disusun sesuai dengan tujuan penggunaan tes itu sendiri karena tes dapat disusun untuk keperluan pretest/ protest, materi tes, tes diagnostic, tes prestasi belajar, tes formatif, dan tes sumatif; 5) Tes hendaknya digunakan dengan untuk memperbaiki proses belajar mengajar; 6) Tes disusun mempertimbangkan proporsi tingkat kesulitan dan kesesuaiannya dengan taraf kemampuan siswa; 7) Petunjuk pengerjaan soal jelas dan sesuai dengan persoalan yang disajikan; 8) Tes disusun dengan memperhatikan kaidah-kaidah penulisan soal pada masingmasing jenis soal; dan 9) Penulisan soal menggunakan bahasa yang benar.

Pengembangan instrumen penilaian pengetahuan perlu dilakukan serangkaian kegiatan atau langkah-langkah penyusunan penilaian autentik yang dikutip dari Abidin (2016) adalah sebagai berikut: 1) Menentukan standar. Penentuan standar pada dasarnya adalah kompetensi pengetahuan yang terdapat pada kurikulum yaitu saat ini dapat dilihat pada kurikulum 2013. Kompetensi pengetahuan dapat diambil langsung dari kompetensi dasar pada kurikulum 2013; 2) Menentukan tugas autentik yang tepat sesuai dengan dimensi proses kognitif. Guru perlu memahami ketepatan tugas autentik dengan dimensi proses kognitif. Guru hendaknya merumuskan tugas autentik dalam pembelajaran dan penilaian sesuai dengan kemampuan siswa. Selain itu, tugas autentik yang dikembangkan memperhatikan kata kerja operasional; 3) Mengembangkan kriteria. Pengembangan kriteria dilakukan dengan cara mengembangkan indikator dan subindikator terhadap konstruk yang akan dinilai; 4) Membuat soal dan kunci jawaban ataupun rubrik penilaian. Sebaiknya guru membuat kisi-kisi penyusunan soal terlebih dahulu. Soal yang dibuat guru dalam rangka membentuk siswa yang kritis, kreatif, inovatif, dan pengetahuan yang mendalam hendaknya soal yang dibuat guru berbentuk soal uraian/ esai/ penugasan bukan soal pilihan ganda. Soal yang baik pada uraian/ esai hendaknya beragam dari tingkat kesukaran maupun domain kognitif; dan 5) Menentukan kunci jawaban dan menyusun rubrik penilaian. Kunci jawaban sebaiknya dilengkapi dengan rubrik penilaian agar hasil penilaian benar-benar autentik dan akuntabel.

Kedua, Taswin, Sailan \& Umar (2018) berpendapat bahwa sikap secara lahiriah dikatakan sebagai suatu kebiasaan bertindak dengan cara tertentu baik secara positif maupun negatif. Positif jika cara itu diwarnai oleh rasa senang atau simpati sedangkan cara negatif apabila didasari rasa antipati. Sikap sebagai kesadaran individu yang menentukan perbuataan yang nyata dalam kegiataan-kegiatan sosial. Delamater \& Myers (2011) mengemukakan empat fungsi penting sikap adalah sebagai berikut: 1) sikap sebagai alat untuk menilai suatu objek; 2) sikap sebagai sarana pembentukan pengetahuan, 3) sikap sebagai pembentuk kepribadian seseorang, dan 4) sikap melindungi seseorang dari perasaan yang mengancam dirinya. Penilaian sikap pada Kurikulum 2013 adalah kegiatan untuk mengetahui kecenderungan perilaku spiritual dan sosial siswa dalam kehidupan sehari-hari. Penilaian ini dilakukan di dalam kelas maupun di luar kelas sebagai hasil pendidikan. Tujuan penilaian sikap adalah untuk mengetahui capaian/ perkembangan sikap siswa yang terdapat pada butir-butir nilai sikap dari KI-1 dan KI-2.

Penilaian aspek sikap dapat dilakukan oleh guru melalui tahapan sebagai berikut: 1). mengamati perilaku peserta didik selama pembelajaran; 2). mencatat perilaku peserta didik dengan menggunakan lembar observasi/pengamatan; 3). menindaklanjuti hasil pengamatan; dan 4). mendeskripsikan perilaku peserta didik (Kemendikbud, 2016). Guru dapat melakukan penilaian sikap melalui observasi, penilaian diri, penilaian antar siswa/ "teman sejawat "(peer 
evaluastion), dan jurnal (Kemendikbud, 2014). Penilaian sikap dilakukan dengan menyesuaikan rumusan Kompetensi Dasar pada Kompetensi Inti 1 (KI-1) dan Kompetensi Inti 2 (KI-2) yang mencakup aspek spiritual dan sosial. Implementasi penilaian sikap yang ada buku kelas IV tema "Daerah Tempat Tinggalku" Subtema 1 "Lingkungan Tempat Tinggalku" Pembelajaran 3 adalah sebagai berikut:

Langkah pertama adalah menetapkan standar. Standar yang dimaksud adalah kompetensi yang terdapat pada kompetensi inti kesatu dan kompetensi inti kedua yang terdapat pada kurikulum 2013 serta kompetensi dasar. Kompetensi Inti 1 (Religius/ Spiritual) "Menerima dan menjalankan ajaran agama yang dianutnya", Kompetensi Inti 2 (Sosial) "Menunjukkan perilaku jujur, disiplin, tanggung jawab, santun, peduli, dan percaya diri dalam berinteraksi dengan keluarga, teman, guru dan tetangga. Sedangkan pada Kompetensi dasar 1.3 Mensyukuri keberagaman umat beragama di masyarakat sebagai anugerah Tuhan Yang Maha Esa dalam konteks Bhinneka Tunggal Ika, 2.3 Bersikap toleran dalam keberagaman umat beragama di masyarakat dalam konteks Bhinneka Tunggal Ika.

Langkah kedua adalah menentukan tugas autentik yang ada pada buku kelas IV tema "Daerah Tempat Tinggalku" Subtema 1 "Lingkungan Tempat Tinggalku" Pembelajaran 3. Tugas autentik dapat dibedakan menjadi dua yaitu pembiasaan dan tugas autentik berupa aktivitas pembelajaran. Pada KI-1 (Religius/ Spiritual) terkait indikator pembiasaan seperti: 1) Berdoa sebelum dan sesudah belajar, 2) Menjalankan ibadah tepat waktu, 3) Memberi salam pada awal dan akhir berkomunikasi, 4) Mengucapkan syukur ketika mendapatkan keberhasilan, dan 5) Mengucapkan istigfar ketika mendapatkan kegagalan. Pada KI-1 (Religius/ Spiritual) terkait indicator aktivitas seperti: 1) Memuji kebesaran Tuhan atas alam yang diamatinya, 2) Bersyukur kepada Tuhan atas ilmu yang diperoleh, dan 3) Bersyukur kepada Tuhan atas keberagaman ciri fisik untuk saling menghargai. Pada KI-2 (Sosial) kerjasama terkait indikator pembiasaan seperti: 1) Berdiskusi memecahkan permasalahan bersama kelompoknya, 2) Memberi pendapat saat diskusi, 3) Membantu teman kelompok yang mengalami kesulitan, 4) Menerima pendapat dari temannya dalam berdiskusi, 5) Dapat beradaptasi dengan kelompoknya, 6) Kompak dalam tim kelompoknya, dan 7) Menunggu giliran saat turnamen. Pada KI-2 (Sosial) kerjasama terkait indikator aktivitas seperti: 1) Menghargai pendapat teman dalam berdiskusi, 2) Memberi pendapat saat kegiatan diskusi, 3) Menunjukkan kekompakan dalam kegiatan diskusi kelompok, 4) Menerima pendapat teman saat diskusi, 5) Mau membantu teman yang membutuhkan bantuan saat kegiatan diskusi kelompok, 6) Mampu beradaptasi dengan teman sekelompok pada kegiatan diskusi tanpa membeda-bedakan. Langkah ketiga adalah mengembangkan rubrik penilaian. Rubrik penilaian pada buku kelas IV tema "Daerah Tempat Tinggalku" Subtema 1 "Lingkungan Tempat Tinggalku" Pembelajaran 3. Penilaian dengan menggunakan skala likert yaitu selalu, sering, jarang, dan tidak pernah.

Ketiga, Penilaian keterampilan pada buku model penilaian autentik dikembangkan untuk mengukur keterampilan siswa yang meliputi keterampilan praktik, produk, dan proyek. Penilaian keterampilan sesuai dengan buku kelas IV tema "Daerah Tempat Tinggalku" Subtema 1 "Lingkungan Tempat Tinggalku" Pembelajaran 3 yaitu penilaian praktik dimana siswa membaca mengenai "Asal Mula Bukit Catu". Penilaian produk dilakukan guru dalam menilai siswa menulis laporan hasil wawancara dengan teman sekelas. Penilaian proyek dilakukan guru dalam menilai siswa terkait menulis laporan sederhana hasil pengamatan lingkungan tempat tinggal. Kemendikbud (2017) menyatakan bahwa penilaian keterampilan adalah penilaian yang dilakukan untuk mengukur kemampuan peserta didik dalam menerapkan pengetahuan dalam melakukan tugas tertentu di berbagai macam konteks sesuai 
dengan indikator pencapaian kompetensi. Penilaian keterampilan tersebut meliputi ranah berpikir dan bertindak. Keterampilan ranah berpikir meliputi antara lain keterampilan membaca, menulis, menghitung, dan mengarang. Keterampilan dalam ranah bertindak meliputi antara lain menggunakan, mengurai, merangkai, modifikasi, dan membuat.

Instrumen penilaian dirancang untuk mengetahui tingkat pemahaman peserta didik setelah mempelajari suatu kompetensi (Prasasti, et all,. 2012). Instrumen penilaian harus memenuhi persyaratan sesuai dengan Permendikbud Nomor 66 Tahun 2013 tentang standar penilaian adalah sebagai berikut: 1) substansi yang merepresentasikan kompetensi yang dinilai; 2) konstruksi yang memenuhi persyaratan teknis sesuai dengan bentuk instrumen yang digunakan; dan 3) penggunaan bahasa yang baik dan benar serta komunikatif sesuai dengan tingkat perkembangan peserta didik. Instrumen penilaian keterampilan pada buku pengembangan model penilaian autentik di SD dilengkapi dengan kisi-kisi penilaian, lembar kerja siswa, dan rubrik penilaian. Rubrik penilaian yang digunakan berupa daftar cek atau skala penilaian (rating scale). Rubrik penilaian mengacu pada indikator yang telah ditetapkan pada kurikulum 2013.

Pengembangan perangkat penilaian keterampilan sesuai dengan langkah-langkah pengembangan penilaian pengetahuan dan penilaian sikap. Langkah pertama yaitu menentukan standar yang ada pada Kurikukum 2013. Standar penilaian Kurikulum 2013 terdapat pada Kompetensi Inti empat (K-4) dan Kompetensi Dasar empat (KD-4) pada masing-masing mata pelajaran. Langkah kedua dalam pengembangan penilaian keterampilan adalah menentukan tugas autentik yang dilakukan siswa. Tugas autentik dikerjakan siswa dalam penilaian membaca cerita, penilaian menulis laporan hasil wawancara, dan penilaian menulis laporan sederhana hasil pengamatan. Langkah ketiga dalam pengembangan penilaian keterampilan adalah membuat rubrik penilaian. Rubrik penilaian yang dibuat mencakup penilaian praktik dalam membaca teks bacaan, penilaian produk dalam menulis laporan hasil wawancara, dan penilaian proyek dalam menulis laporan sederhana hasil pengamatan.

Pengembangan penilaian autentik di SD pada kurikulum 2013 ini sesuai dengan pendapat Legaspi et al (2020) bahwa penilaian autentik seringkali dilakukan oleh guru pada siswa yaitu siswa kelas IV sekolah dasar. Sejalan dengan pendapat Omasta, et all (2020) bahwa guru dapat mengkonseptualisasikan penilaian teori dan praktik melalui pengembangan penilaian yang berkualitas ditingkat sekolah dasar. Ani (2014) berpendapat bahwa, melalui penilaian, guru dapat mengembangkan kompetensi yang dimiliki setiap siswa. Adapun kompetensi yang diharapkan dan dikuasai oleh siswa setelah proses belajar mengajar adalah kompetensi sikap, keterampilan dan pengetahuan. Salah satu penekanan dalam kurikulum 2013 adalah penilaian autentik, dimana penilaian yang dilakukan tidak hanya hasil akhirnya saja tetapi juga proses selama pembelajaran berlangsung. Oleh karena itu, guru harus mengetahui mekanisme, prosedur dan instrumen penilaian hasil belajar siswa sesuai dengan kompetensi yang ingin diukur. Kompetensi yang diukur melalui penilaian autentik menggambarkan tuntutan kompetensi yang ada di standar kompetensi (SK) atau Kompetensi Inti (KI) dan Kompetensi Dasar (KD).

Pengembangan model penilaian autentik pada kurikulum 2013 di SD memenuhi kelayakan dari segi materi, isi, dan bahasa dengan skor sebesar 68 atau 94\% dengan kategori "sangat valid". Hal ini sejalan pendapat Bhakti et al (2013) bahwa Penilaian untuk validator dibedakan kedalam penilaian ranah bahasa, ranah kontruksi, dan ranah materi. Buku model penilaian autentik ini dikembangkan sesuai dengan tahapan Gall, Gall \& Borg (2003) adalah sebagai berikut:1) adanya kebutuhan guru terkait buku petunjuk penilaian kurikulum 2013 yang mudah diapahami oleh guru khususnya guru SD;2) Pengumpulan data diperoleh melalui hasil 
wawancara dan angket pada guru SD di Majalengka Kulon II, Jatipamor, dan Munjul; 3) Desain produk berupa buku petujuk yang dibuat dilengkapi dengan landasan teori, instrumen yang digunakan dalam penilaian autentik, langkah-langkah penilaian autentik dan implementasi pengembangan penilaian autentik sesuai dengan buku kelas IV tema "Daerah Tempat Tinggalku" Subtema 1 "Lingkungan Tempat Tinggalku" Pembelajaran 3; dan 4) Validasi desain buku petunjuk penilaian kurikulum 2013 dilakukan oleh para ahli dari dosen, instruktur kurikulum, dan praktisi.

Implementasi pengembangan penilaian autentik perlu dilakukan beberapa tahapan sebagai berikut: 1) tahap menentukan standar yang akan diukur, 2) menentukan konstruk yang dinilai, 3) menentukan tugas autentik yang akan dikerjakan siswa, 4) mengembangkan kriteria penilaian, dan 5) menyusun rubrik penilaian (Abidin, 2016). Penilaian autentik yang dikembangkan memiliki karaktersitik antara lain: 1) berpusat pada peserta didik, 2) terintegrasi dengan pembelajaran, 3) autentik, 4) berkelanjutan, 5) individual, 6) mengembangkan kemampuan berpikir tingkat tinggi, 7) kemauan mengambil resiko, 8) berpikir kreatif, 9) tanggungjawab terhadap tugas dan karya, dan 10) memiliki rasa kepemilikan (Abidin, 2016). Adapun prinsip khusus dalam Penilaian Autentik meliputi:1) materi penilaian dikembangkan dari kurikulum, 2) bersifat lintas muatan atau mata pelajaran, 3) berkaitan dengan kemampuan peserta didik, 4) berbasis kinerja peserta didik, 5) memotivasi belajar peserta didik, 6) menekankan pada kegiatan dan pengalaman belajar peserta didik, 7) memberi kebebasan peserta didik untuk mengkonstruksi responnya, 8) menekankan keterpaduan sikap, pengetahuan, dan keterampilan, 9) mengembangkan kemampuan berpikir divergen, 10) menjadi bagian yang tidak terpisahkan dari pembelajaran, 12) menghendaki balikan yang segera dan terus menerus, 13) menekankan konteks yang mencerminkan dunia nyata, 14) terkait dengan dunia kerja, 15) menggunakan data yang diperoleh langsung dari dunia nyata, dan 16) menggunakan berbagai cara dan instrumen (Mendikbud, 2014).

\section{Kesimpulan}

Berdasarkan tahapan kegiatan penelitian yang telah dilaksanakan dapat dikemukakan kesimpulan pada penelitian adalah sebagai berikut: 1) Pengembangan buku model penilaian autentik pada kurikulum 2013 di SD meliputi tiga aspek yaitu aspek pengetahuan, sikap, dan keterampilan yang difokuskan pada model berbasis masalah sehingga mudah dipahami dan digunakan guru; 2) Buku model penilaian autentik kurikulum 2013 di SD memenuhi kriteria kelayakan sehingga dapat digunakan oleh guru SD sebagai petunjuk dalam mengembangkan penilaian autentik. Keterbaharuan pada buku ini dilengkapi dengan landasan teori, instrumen yang digunakan, langkah-langkah pengembangan penilaian autentik, serta contoh implementasi penilaian kurikulum 2013 yang meliputi penilaian pengetahuan, sikap, dan keterampilan.

\section{Daftar Pustaka}

Abidin, Y. (2016). Revitalisasi Penilaian Pembelajaran: dalam Konteks Pendidikan Multiliterasi Abad Ke 21. Refika Aditama.

Abidin, Yunus. (2016). Revitalisasi Penilaian Pembelajaran: dalam Konteks Pendidikan Multiliterasi Abad Ke 21. Refika Aditama.

Anderson, L \& Kratwohl, D. R. (2015). Kerangka Landasan Untuk Pembelajaran, Pengajaran, dan Assesment. Pustaka Belajar.

Ani, Y. (2014). Penilaian Autentik dalam Kurikulum 2013. Seminar Nasional Implementasi 
Kurikulum 2013, 742-749.

Baiduri, et all. (2019). PENGEMBANGAN INSTRUMEN PENILAIAN AUTENTIK KURIKULUM 2013 PADA MATA PELAJARAN MATEMATIKA. JINoP (Jurnal Inovasi Pembelajaran), 5(1), 1-5. http://ejournal.umm.ac.id/index.php/jinop

Bhakti, A. S. (2014). Pengembbangan Model Penilaian Autentik Berbasis Kurikulum 2013. Universitas negeri Malang.

Daji, Mulyasa, \& Warta, W. (2019). IMPLEMENTASI SISTEM SEKOLAH MENENGAH PERTAMA. NER, 1 Nomor 2(April), 57-64.

Delamater, J. D dan Myers, J. M. (2011). Social Psychology (Seventh Ed). Wadsworth, Cengage Learning.

Endra, I. M., Merta, D., Suarjana, I. M., Putu, L., \& Mahadewi, P. (2015). ANALISIS PENILAIAN AUTENTIK MENURUT PEMBELAJARAN KURIKULUM 2013 PADA KELAS IV SD NO . 4 BANYUASRI Universitas Pendidikan Ganesha. 3(1), 1-10.

Enggarwati, N. S. (2015). KESULITAN GURU SD NEGERI GLAGAH DALAM MENGIMPLEMENTASIKAN PENILAIAN AUTENTIK PADA KURIKULUM 2013. Artikel Jurnal UNY, 151, 10-17. https://doi.org/10.1145/3132847.3132886

Gall, Meredith. D; Gall, Joyce. P; Borg, W. R. (2003). Educational Research An Introduction (7th Edition). Pearson.

Haryanti, Y. D \& Saputra, D. S. (2019). Instrumen Penilaian Berpikir Kreatif Pada Pendidikan Abad 21. Jurnal Cakrawala Pendas, 5(2), 58-64.

Kemendikbud. (2014). Konsep dan Implementasi Kurikulum 2013. Jakarta: Kementrian Pendidikan Dan Kebudayaan.

Kemendikbud. (2016). PERMENDIKBUD no.23 Tahun 2016 tentang Standar Penilaian. https://doi.org/10.1017/CBO9781107415324.004

Kemendikbud. (2017). Panduan Penilaian Oleh Pendidik dan Satuan Pendidikan Sekolah Menengah Pertama. Kementerian Pendidikan dan Kebudayaan Direktorat Jenderal Pendidikan Dasar dan Menengah Direktorat Pembinaan Sekolah Menengah Pertama.

Legaspi, J. M. E., Perhiliana, C. O., Camayang, J. G., Garingan, E. G., Kristine, M., Velasco, G. T., Ursua, J. C., \& Bautista, J. R. G. (2020). Scientific Learning Motivations as Predictors of Pre- service Elementary Grade Teachers ' Authentic Assessment Practices in Science. American Journal of Educational Research, 8(3), 150-154. https://doi.org/10.12691/education-8-3-4

Matt Omasta, et all. (2020). Assessment in elementary-level drama education: Teachers' conceptualizations and practices. Arts Education Policy Review, 1-15. https://doi.org/DOI: 10.1080/10632913.2020.1746710.

Mendikbud. (2014). PENILAIAN HASIL BELAJAR OLEH PENDIDIK PADA PENDIDIKAN DASAR DAN PENDIDIKAN MENENGAH. PERATURAN MENTERI PENDIDIKAN DAN KEBUDAYAAN REPUBLIK INDONESIA NOMOR 104 TAHUN 2014, 13, 13,23. http://pgsd.uad.ac.id/wp-content/uploads/lampiranpermendikbud-no-104-tahun-2014.pdf

Munawati, S. (2017). Pelaksanaan Penilaian Autentik di Sekolah Dasar Negeri Pujokusuman I Yogyakarta. Jurnal Pendidikan Guru Sekolah Dasar, 2(6), 174-183.

Permendikbud Nomor 66 Tahun 2013. (2013). Standar Penilaian Pendidikan. Kemendikbud.

Prasasti, Y. R., Suyono dan Basuki, I. A. (2012). Pengembangan Instrumen Asesmen Berpikir Kritis melalui Membaca untuk Siswa SD/MI. Jurnal Universitas Negeri Malang, 48(2), 1-12.

Setiamiharja, R. (2012). Penilaian Berbasis Kelas. HSAA Press.

Taswin, H.,Sailan, M \& Umar, F. (2018). Pelaksanaan Penilaian Sikap Sosial Mata Pelajaran PPKN Berdasarkan Kurikulum 2013 Di SMAN 13 Makassar. Jurnal Tomalebbi, 5, 1. https://ojs.unm.ac.id/tomalebbi/article/view/6764.

Villarroel, V., Boud, D., Bloxham, S., Bruna, D., \& Bruna, C. (2019). Using principles of authentic assessment to redesign written examinations and tests. Innovations in Education and Teaching International, 00(00), 1-12. https://doi.org/10.1080/14703297.2018.1564882

Wildan, W. (2017). Pelaksanaan Penilaian Autentik Aspek Pengetahuan, Sikap Dan Keterampilan Di Sekolah Atau Madrasah. Jurnal Tatsqif, 15(2), 131-153. 
https://doi.org/10.20414/jtq.v15i2.3

Yamin, M. Y. M. (2018). Pelaksanaan Penilaian Autentik Kurikulum 2013 Pada Pembelajaran Tematik SD Gugus Markisa Kota Banda Aceh. Jurnal Ilmiah Pendidikan Guru Sekolah Dasar, 2(3), 1. 